\title{
The Political Ecology of Cereal Seed Development in Africa: A History of Selection
}

\author{
James C. McCann
}

Abstract Agricultural history and the history of seeds in sub-Saharan Africa are an aggregate effect of
individual day-to-day decisions by farmers. The role of seeds within an agricultural system can be a valuable
indicator of both social and natural time since farmers' seed selections indicate both natural conditions -
moisture, pests, soils - and short-term, season by season farm decisions about labour, potential yield vs risk and
market potential. In the immediate future, international donors and African governments are planning that
African farmers will receive their seeds from a global political structure that anticipates, perhaps wishfully,
economic and political stability. Those expectations of development specialists are ones that failed at the end of
the twentieth century. Will seed selection by African farmers in the twenty-first century take place in an ideal
free market of infinite choice or in real-world conditions fraught with uncertainty of supply, climate
fluctuations and unintended consequences within complex local ecologies?

1 The co-evolution of seeds and society

Agricultural history and the history of seeds in sub-Saharan Africa are an aggregate effect of individual day-to-day decisions by farmers. The role of seeds within an agricultural system can be a valuable indicator of both social and natural time, since farmers' seed selections indicate both natural conditions - moisture, pests, soils - and short-term, season by season farm decisions about labour, potential yield versus risk and market potential.

Seeds are the means by which humans propagate flora that provide the foundations of social and physical reproduction: food, fibre, fuel and construction materials. Recent efforts to transform African agriculture through seed development are part of a longer chronology of change and adaptation visible historically across Africa's historical landscapes. Seeds co-evolve with human society and economy and constitute a body of complex historical activity that includes the ideas, exigencies and economic life of farmers. Through examining indirectly genetic materials stored in seeds - by noting the phenotypes that appear in African farmers' fields - it is possible to reconstruct, at least in theory, the accumulation of knowledge, of human action and of the serendipity of climate, soils and economic exigencies of the past. Above all, the history of seed is a chronology of the accumulation of farm-level selection of preferred kinds of plants, food and landscapes that chronicle Africa's agrarian past.

African farmers' choices about crops rarely appear within the framework of eventful time and are therefore poorly documented in traditional historical sources. Nevertheless, the accumulated effects of these mundane farm-level decisions appear over the longue durée, or long term, as trends in production reflecting long-term changes in the ecologies of production. Agrarian landscapes are thus the ultimate canvas where those historical choices appear, albeit in broad strokes.

The production and use of seeds is a subset of the political ecology of agriculture. Modern seeds and the pace of their changing context differ from older seed types in terms of the process of selection and the agents of the selection decisions made, whether those choices result from a farmer sorting through their own fields' product, borrowing from a neighbour, purchasing 
a woven plastic sack of commercial seed from a shop or accepting an improved seed allocation from a government extension worker.

Cereal seeds have a role in Africa's history that includes its original genetic endowments of vital cereal species (sorghum, millets, teff) and secondary innovation of other cereals (maize, wheat, barley, rice, oats) imported over several hundred years. Historically, farmer adoption and selection of cereals took place alongside their adoption of vegetatively propagated food crops like bananas and tubers (e.g. cassava, potato, yam). Cereals also differed from insect-pollinated fruits and legumes such as capsicum peppers, fava beans, tomatoes or eggplant from perennial plants, in that cereals were either fully selfpollinating (wheat, rice, millet), partially selfpollinated (sorghum) or wind-pollinated (maize) plants that farmers cultivated annually in farm plots. The largely unremarked historical evidence for African farmers' selection of traits from cereal seeds that they preferred stands in stark contrast to the modern, highly visible action of international donors to jump-start an African Green Revolution through the introduction of new manipulated genetics of seeds to address issues of food security, economic development and African seed market access for private corporations.

Africa's diverse geography and history has resulted in a unique political ecology of its cereal cultivation and seed genetics at play over time. This article considers the political ecology of cereal seeds in two dynamic contexts: one is the changing mix of cereal seeds planted in a particular agro-ecology (Ethiopia) and the other is the evolution of the seed history of one particular crop, maize - Africa's dominant cereal in the past century - and its history in East and Southern Africa.

While sub-Saharan Africa was home to three distinct zones in which food production arose (the Sahel zone, tropical West Africa and the Ethiopian highlands), Africa had fewer endowments in genetic materials of plants and animals available for domestication than other parts of the world. This is particularly true in the global distribution of cereals (i.e. large-seeded grass species - the ancestors of wheat, barley, rice and rye) that made up the raw material from which humans could domesticate cereals via seed selection. Western Asia, Europe, North
Africa and England had a total of 33 cereals and the Americas had another 11, while Africa had only four of the world's total of 56 (Diamond 1997). ${ }^{1}$ The development of Africa's full array of seed materials thus included generations of farmer community selections, a continuous importation of seed types via regional trade and individuals' selections from their own fields and husbanded seed storage (McCann 2005).

A simple list of Africa's limited genetic endowments of the flora and fauna of food sources, however, underplays the dynamism of Africa's wider physical and human geography. Ironically, of course, humankind itself had its earliest florescence in Africa where gathering and hunting activities sustained human food sources and eventually fostered the skills in foraging and later in the cereal agriculture that Lucy's descendants took with them on their global expansion. For African farmers themselves, those interactions took place across penetrable ecological borders (the Sahara), along natural corridors of trade (the Nile Valley), together with ocean currents (the Indian Ocean rim), and ultimately along tightly organised trade/exchange networks of peoples, seed endowments, and agronomic strategies.

\section{Reconstructing seed history in Ethiopia, 1938-90}

Ethiopia provides a prime example of the historical processes of seed dispersal and development, as well as the changing dynamics of seed patterns with local agro-ecologies in historical contexts and in the rapid adaptations of the late twentieth century. The best historical evidence indicates strongly that the current bundle of cereal cultigens present in Ethiopia today were also present a century and a half ago. For many years, the conventional wisdom of both academics and agricultural specialists held that Ethiopia's highland farms concentrated primarily on teff, barley and wheat as the basis of production and local consumption. Other cereals like sorghum, millet and maize were secondary, though they played a role in farmers' risk aversion.

Historians of Ethiopia do not have detailed time series data for cropping patterns either for major regions or single localities. Historical records archives, traveller accounts, farm interviews - can, however, provide sufficient evidence to reconstruct general patterns, such as localised qualitative data 
Table 1 Cereal production in Ethiopia by grain, 1938

\begin{tabular}{|c|c|c|c|c|c|c|}
\hline Grain & \multicolumn{2}{|r|}{ Tons } & \multicolumn{4}{|c|}{ Percentage of total } \\
\hline Sorghum & \multicolumn{3}{|c|}{165,000} & \multicolumn{2}{|c|}{23.0} & \\
\hline Teff & \multicolumn{3}{|c|}{162,000} & \multicolumn{2}{|c|}{22.6} & \\
\hline Barley & \multicolumn{3}{|c|}{192,000} & \multicolumn{2}{|c|}{26.7} & \\
\hline Wheat & \multicolumn{3}{|c|}{75,000} & \multicolumn{2}{|c|}{10.5} & \\
\hline Maize & \multicolumn{3}{|c|}{97,000} & \multicolumn{2}{|c|}{13.5} & \\
\hline Millet & \multicolumn{3}{|c|}{25,000} & \multicolumn{2}{|c|}{3.4} & \\
\hline \multicolumn{7}{|c|}{ Table 2 Regional distribution of cereal production, 1938 (\%) } \\
\hline Region & Sorghum & Teff & Barley & Wheat & Maize & Millet \\
\hline Eritrea & 18.1 & 24.7 & 33.9 & 46.4 & 6.2 & 48.0 \\
\hline Amara & 30.3 & 49.4 & 23.4 & 8.0 & 15.5 & 20.0 \\
\hline Shoa & 6.1 & 9.2 & 20.8 & 26.6 & 10.3 & 8.0 \\
\hline Harar & 33.3 & 4.3 & 18.2 & 16.5 & 16.5 & - \\
\hline \multirow[t]{2}{*}{ Galla and Sidamo } & 12.2 & 12.4 & 3.7 & 2.7 & 51.5 & 24.0 \\
\hline & 100.0 & 100.0 & 100.0 & 100.0 & 100.0 & 100.0 \\
\hline
\end{tabular}

Table 1 and 2 sources Author's own calculations based on Governo Generale dell'Africa Orientale Italiana \& Direzione Superiore degli Affari dell Colonizzasione e Lavoro (1940), Istituto Agricolo Coloniale (1946), Ufficio Agrario della Colonia Eritrea (1940).

on crop patterns for the mid-nineteenth century (Crummey 1983). ${ }^{2}$ There is also 'snapshot' benchmark data for the year 1938 and again for the more recent period 1963-83. ${ }^{3}$ The data drawn from macro-level sources compare in a general way with localised qualitative and quantitative data, which in most cases provide details that illuminate the causes and local effects of major statistical trends. At the local level, interviews with farmers, farm life histories, and participant observation help explain the rationale for seed choices (i.e. market conditions, environment, risk aversion, etc.) and add a nuanced human dimension to longterm patterns of crop landscapes.

\subsection{The 1938 benchmark}

In 1938, an Italian team from the Istituto Agricolo Coloniale in Florence compiled data on cereal production in Italian East Africa (comprising Ethiopia, Eritrea and Somaliland). These data, shown in Tables 1 and 2, when adjusted for boundary changes, provide a useful metric against which to measure macro-level changes in production. ${ }^{4}$
Overall, these figures probably represent the cropping for cereals through most of the nineteenth and twentieth centuries. They also indicate the wide variation in cropping (i.e. seed) choices made by farmers across local agroecologies. The Italian survey, though helpful, does not offer specific information on the sources of seed or the process of selection. We do know that Italian colonial planners sought to address their country's hunger for wheat by importing seed from Italy and Kenya to promote higher yields. The 1937 Kenyan seed arrived too late for June sowing, but the fact that Italian officials did expect those seeds shows the existence of seed exchanges between regions and colonial networks by the 1930s. The science of seed transfers was in its infancy: the seeds did not work and Italian 'improved' seeds, called mentana and quaderna (probably soft bread wheat varieties) failed miserably when they succumbed to the wheat rust Puccinia gramminis. Italian planners quickly reverted to local seeds that local African farmers had long selected for rustdisease resistance (Larebo 1994). 


\begin{tabular}{|c|c|c|c|c|c|c|}
\hline & Barley & Teff & Sorghum & Maize & Wheat & Millet \\
\hline 1961-2 & 26.51 & 25.29 & 20.00 & 14.18 & 13.10 & n.d. \\
\hline 1966-7 & 26.55 & 24.02 & 20.62 & 15.65 & 13.17 & n.d. \\
\hline 1970-1 & 26.38 & 23.04 & 22.33 & 15.31 & 12.94 & n.d. \\
\hline $1974-5$ & 15.33 & 23.38 & 15.59 & 23.71 & 18.43 & 3.56 \\
\hline 1975-6 & 10.51 & 22.77 & 19.12 & 30.62 & 11.24 & 5.75 \\
\hline 1976-7 & 19.25 & 24.48 & 16.76 & 22.31 & 10.84 & 4.62 \\
\hline 1977-8 & 17.03 & 27.37 & 16.77 & 23.38 & 10.84 & 4.62 \\
\hline 1978-9 & 16.62 & 28.34 & 15.56 & 24.15 & 11.20 & 4.04 \\
\hline 1979-80 & 15.56 & 23.38 & 27.19 & 23.39 & 7.81 & 2.66 \\
\hline 1980-1 & 19.05 & 25.58 & 26.48 & 15.85 & 9.32 & 2.87 \\
\hline 1981-2 & 17.74 & 21.97 & 23.35 & 21.67 & 11.53 & 2.85 \\
\hline $1982-3$ & 17.06 & 22.01 & 20.89 & 23.75 & 12.40 & 2.99 \\
\hline 1983-4 & 15.52 & 20.57 & 21.75 & 28.30 & 10.73 & 2.68 \\
\hline
\end{tabular}

Attempts to use imported seed to combat crop disease elsewhere in colonial Africa also took place in the 1949-53 outbreak of what officials called 'the American Rust' (Puccinia polysora) that threatened maize yields across colonial Africa. Officials from British, French and Portuguese colonial agriculture stations revealed a global network of seed when they appealed for seed to try and select for resistance to the American Rust. Small shipments of seed corn, a few ounces at a time, arrived at various colonial seed research stations by post and courier from private seed companies, university faculty, embassies, research stations and farmers' associations around the globe. Once the research stations began formal trials in the $1950 \mathrm{~s}$, the flow of genetic materials to African colonial research stations changed from a trickle to a flood. By May, East African Agricultural Research working on the American Rust claimed that multilateral sources in Africa and the Americas had provided more than 200 sample seed types from around the world. The process of transferring and exchanging genetic materials in seeds between continents and across global biomes appeared effortless and quick, and rationally planned, in contrast to the first biological transfers of the Columbian Exchange that had been halting and often serendipitous (McCann 1995).
2.2 Trends in cereal seed and cropping, 1963-90

If colonial seed networks were operating by the 1950s, non-colonial settings, like Ethiopia, were also showing signs of changing seed distribution that underlay changes in cropping patterns. In 1988, Dr Ian Watt of the Department of Geography of Addis Ababa compiled data which traced patterns in Ethiopia's cereal production over the previous three decades (Watt 1988). These data, presented in Table 3, indicate that the most significant long-term trends evident nationally had been the steady decline in barley, a highland crop, which moved from the dominant cereal nationally to third rank, and the increasing role of maize, a mid-altitude crop, which had come to dominate southern Ethiopia, though not as thoroughly as it has the cropping systems of East and Southern Africa (see below). Highland Ethiopia's own indigenous cereal, teff, had expanded its strong position and surpassed barley as the major crop in the mid-1960s, probably reflecting both urban tastes and cropping specialisation in intense cereal production areas in the highlands.

The overall evidence of changes in cereal cropping patterns and seed types indicates clearly that farmers' selection of cereal seeds were relatively stable in the short term, but subject to change at a macro-level over the long term. The preliminary data allow identification 
of specific changes in cropping and to examine possible causes. The introduction of commercial seeds played only a marginal role (e.g. Kenyan Katumani composite maize seed) in national changes in cropping.

The major trend in cropping appears to be the shift to lowland and mid-altitude crops both in terms of national percentages and in specific locations. In the first instance, the expansion of cultivation to marginal lowland areas in the past one to two generations probably accounts for the stability of sorghum and the rapid expansion of maize in the national cropping mix. At the same time, maize has expanded because its agronomic characteristics (low labour, short cycle) suited the expansion of coffee cultivation, the need to double-crop on shrinking household plots, and demands for off-farm labour during the socialist period in the 1980s. The negative implications of such seed/cropping trends in Ethiopia - and probably elsewhere in Africa - are not the result of bad decisions by farmers, but overall economic and political conditions which threatened food security in an era of sustained drought.

\section{Maize seed and Southern Africa, 1500-2010}

Ethiopia's case in a historically diverse seed ecology contrasts sharply with the chronology and dynamism of maize seed's history in East and Southern Africa. As Africa's primary cereal crop, the history of maize seed indicates that there are five discernible stages of seed development and distribution in Southern Africa that connect Africa's local seed histories with global trends. Maize moved to Africa from the New World initially as seed and not as a food commodity.

\subsection{Stage 1: Maize, the vegetable, 1500-1900}

Zea Mays is a New World crop that came to Africa after the opening of the Atlantic world, post1500. Maize moved to Africa along routes of exchange and sites of encounter with European transatlantic trade as well as internal routes in the Nile Valley, travelled east to west with the Islamic hajj and with the Swahili caravan trade. By the early 1700 s, maize seed was already well entrenched in the Nile Valley and in West Africa. In these places, maize seed arrived in a kaleidoscope of forms and colours (red Caribbean flints, yellow and blue floury types and eventually, white American dents). Maize's reception as seed onto African farms depended from the beginning on local ecologies and food systems. Maize's most important early roles early in African farming systems was as a vegetable crop cultivated in household gardens and consumed green during the long hungry season that proceeded the sorghum or millet harvest. In West and Central Africa's forest ecologies maize served as a pioneer crop broadcast in cleared plots within the forest fallow cropping system that allowed human populations to spread into forest zones (McCann 1995).

In Southern Africa, maize appeared late relative to other areas (not until the late seventeenth century) and, as in West Africa, served as a hungry season vegetable garden crop, where sorghum or millet as the staple cereals and livestock were the most important sources of protein and social capital. The early Southern African maize varieties imported as seed and selected by farmers from their fields and granaries were largely flinty and quick maturing in character, well adapted therefore to the stress of Southern Africa's capricious climate and long dry season. By the middle of the 1800s, maize appeared in most of Africa's farming and livestock systems, but nowhere had it become a dominant staple or one produced as a commercial grain crop. Southern Africa maize varieties in the mid-1800s were early maturing flint type seeds of various colours with characteristic hard starch, including Botman (white and yellow), Cango (white and yellow), Repatriation (yellow), Bushman (yellow) and what European farmers called 'Kaffir mielies' (mixed white, red, blue and yellow-coloured flinty land races). For farmers selecting seeds for the next year's planting, maize's chief quality was not its yield but its neat fit within the annual seasonal cycle of food. These garden maize types probably benefited from kraal manure but also had to survive the vagaries of erratic rainfall, disease and low soil fertility. Although we know few of the details, farmers for the most part selected seed from their own stocks on the cob or exchanged some of them with neighbours, choosing qualities like colour, resistance to weevils, storability and shape of the kernels. Across Africa, genetic diversity of local seed was significant and African maize evolved within agro-ecological niches under farmer selection and abiotic stresses of drought or low soil fertility within local agro-ecological niches. Maize thus co-evolved with Southern Africa's political ecology of colonialism, racism and economic change. 


\subsection{Stage 2: New dents for old flints, 1900-60}

In most areas of Southern Africa, maize remained a flinty green vegetable until the post1867 mineral revolution in South Africa, which created a demand for bulk calories in growing cities and mine hostels. The response of small farmers to these new market opportunities was astonishing; e.g. in 1873, Basutoland alone exported over 8,000 metric tons of grain to the new town markets, perhaps a third of it maize. By 1893, export figures had more than doubled annually to include 6,000 tons of maize. By 1900, the region's economy displayed an African smallholder response to urbanisation and the region's links to international markets, and maize quickly superseded former agricultural staples of sorghum, milk and cattle. More significantly, these changes redefined maize from a garden vegetable to a commodified grain. Farmers on smallholdings as well as Europeans on commercial farms had to select seeds to respond to maize's changing status as both a bulk food and a seasonal fresh vegetable. New urban consumers ate their maize not as a milky stage snack, but as 'mealie' flour, reflecting farm-level seed choices from among traits of maturation, flour texture and storability.

In addition to broadened market access, trade brought the deliberate importation of new seeds suited to an increasingly large-scale food production system which began to replace the black smallholder farms that had been the first to respond to the new demands for food grain. Sometime prior to 1898 , a critical introduction from these contacts was a new type of maize seed: American white dent types, bearing homespun names such as Boone County, Iowa Silver Mine, Hickory King and Horsetooth, arrived on the South African veld and later in the Rhodesias. New World dent maize, in contrast to flint maize, its hard-starched cousin, had not only higher yields than older maize varieties and sorghum, but also had a soft starch and uniformity of colour and texture suited to the mechanised milling of mining towns and new high-veld urban areas. The most important of these early seed imports was the medium-late white dent maize known as 'Hickory King', which was to become one of the most important progenitors of South African commercial maize types over the course of the twentieth century. Hickory King produced an eight-row, largekernelled dent variety whose growth tolerated poor soils and out-yielded the older flint maizes. Importation of these new American seeds came from choices by commercially minded seed importers working with large estates, rather than black farmers working small household plots who selected from local stock. The response to the new seeds in the long term came as well from smallholding households who had lost male labour to mines and large commercial farms.

In Stage 2, maize shifted from a black smallholder's crop to a grain crop cultivated on commercial farms on South Africa's burgeoning 'Maize Triangle' in the Orange Free State and Transvaal and increasingly on the plateau of the Rhodesias. Dent maize seed offered the possibility of maize production on an industrial scale for export and what had been a black sharecroppers' crop now had become a staple of large-scale white commercial farms and, to a lesser degree, from black smallholder farms near cities and mines. ${ }^{5}$

Under the control of commercial farmers in the early decades of the twentieth century, these white dent types became progenitors of the first generation of Southern Africa's open-pollinated varieties (OPVs) of seed. As commercial farming expanded in the $1920 \mathrm{~s}$, farms began to specialise in particular product types in livestock and seed corn displayed at agricultural shows and in agricultural publications. Certain farms championed the breeding by mass selection of purebred lines of Salisbury White or Southern Cross or Hickory King, all OPVs. The breeding method in this first OPV era was rigorous selection of seed that promised consistency in yield, colour and disease resistance. Breeders made those selections of the best seed grain from isolated plots cultivated under optimal conditions of rainfall and fertility and sought to develop a genetically homogenous product that had to appeal to millers, international grain traders and shopkeepers. Production on this grand scale made maize in South Africa potentially an exportable commodity valued more in international markets as an industrial raw material (starch) than as a subsistence grain. In this era, commercial seed production has surpassed local farm seed selection.

Dent maize seed also provided a direct link to an international revolution in dryland agriculture, centred in the American Mid-west, that had 
begun to leapfrog worldwide into Canada, Argentina, Brazil, Australia and after 1917, the Soviet Union (Beinart and Coates 1995). The emerging global scale of maize production in Southern Africa encouraged both homogenisation of maize grain itself and a centralisation of breeding and marketing of seed types. Strategies of maize-breeding and seed production were a fundamental ingredient in that change. These processes were to have their full expression in the second half of the twentieth century.

\subsection{Stage 3: High yield, high management, 1960-95}

In 1932, Rhodesia's Salisbury Agricultural Experimental Station, alongside counterparts in South Africa, began a specific effort to improve the varieties of open-pollinated maize being grown on commercial farms by inbreeding classic white dent to form distinct 'heterotic' groups; the first step toward seed hybridisation. ${ }^{6}$ The breeders used the OPV maize variety seed already cultivated by the white families on the Rhodesian commercial farms. Those open-pollinated varieties were the pure white dent types of Salisbury White, Hickory King, Southern Cross and Potchefstoom Pearl. The effort seems largely to have ignored the local and colourful 'land races' - flint types that African farmers still cultivated as 'green mielies' on their diversified farms.

As in the USA, during the same period, the Rhodesian researchers worked to isolate these open-pollinated seed varieties gathered from the region. Seed production of hybrid maize became the priority for research in Southern Rhodesia and South Africa because of its potential in the prime heavy-soiled agricultural lands controlled by white commercial farmers and the possibilities for supplying the growing urban centres with the white maize flour that had rapidly become the regional favourite staple. Maize in the minds of Southern Rhodesia's planners and seed breeders had decidedly become an industrial grain, and not a fresh vegetable to round out rural diets.

The hybrid seed breakthrough in Southern Africa came in October 1958 when the Rhodesian breeders crossed two inbred parent OPV lines to produce SR-52, the world's first commercially successful single-cross hybrid. Although the Salisbury Station had begun working with double-cross hybrids in the late 1930 s and 1940 s, by the late 1950 s they had taken the unusual step (especially in contrast to their American counterparts) of concentrating their efforts on single-cross techniques. Singlecross hybrids are the product of two parent lines - or heterotic groups - that breeders select and 'clean' over several generations to focus on particularly desirable traits. Once breeders establish the parent lines in a pure form, they then cross-pollinate the two parent lines to achieve heterosis, the effect of 'hybrid vigour'? Such 'single' crosses often produce high yields in the first generation (F-1) but generally, the high yield deteriorates rapidly in the next $(\mathrm{F}-2)$ generation, unless farmers buy new seeds each season. The decline in yield in second generation (F-2) varieties with single crosses is even more pronounced than with double-cross hybrids. Moreover, the parent lines need to be kept pure, as breeders must turn the process of commercial seed production over to farmers who need to manage the parent lines on a large scale in order to multiply the seed and release it commercially for use on farms. ${ }^{8}$

SR-52 changed the history of Southern Africa, in that it offered astoundingly high yield (as much as ten tons/ha), although it also required ideal conditions of moisture, nitrogen-rich soil, and timely management. To create SR-52, the Rhodesian breeders had created optimal conditions on their research station and had intended their creation would receive the same treatment on the farm, i.e. a high-yield, highmanagement strategy that characterised the 1960-2000 era. The SR-52 result pre-dated Asia's Green Revolution by half a decade and highlighted the economic benefits of investments in research. In the first years after its 1960 release, SR-52 produced yields 46 per cent higher than its parent OPV lines and tripled maize yields compared with the pre-1960 decade, providing an average of almost five tons per hectare. On some farms, SR-52's results even surpassed US Corn Belt yields. By the years 1976-80, i.e. just before Zimbabwe's independence, virtually all commercial farms in the Rhodesias (i.e. Zambia and Zimbabwe) adopted it. Because it was long maturing and required early planting, SR-52 and later shortseason hybrids rewarded intense management from farmers: the use of tractors, nitrogen fertiliser and the large scale of commercial farms, making Rhodesia's commercial farms viable in world market terms. Irrigation in 
October, prior to the rains on many Rhodesian commercial farms, gave germination a head start and increased its prodigious yields even more. To satisfy the burgeoning regional seed markets, Southern Rhodesia's Department of Agriculture and the Seed Maize Association had established a sophisticated network of farms to produce high-yield/high-management seed - a complex and demanding task. In fact, some might claim that this network of large seed-producing farms was as defining an achievement as the hybrid seeds themselves.

At the height of this era in the 1975-90 period, economists assumed that both the political and economic stability were sustainable and called the phenomenon 'Africa's Emerging Maize Revolution' (Byerlee and Eicher 1997). The assumption that expanding hybrid seed coverage was the solution to national food security in Southern Africa has, however, proven a false hope as food crises in Zimbabwe, Malawi and even South Africa in the late 1990s and early twenty-first century have resulted from drought, the breakdown of economic infrastructure and political conflict. Over the course of the highyield, high-management hybrid era, farmers on smallholdings in Southern Africa found themselves in an ambiguous position. In many cases they had responded with enthusiasm to hybrid seed and fertiliser packages, particularly when credit and stable fertiliser prices were readily available. Zimbabwe was the poster child for smallholder participation as hybrid use in that country in the 1975-90 period rose to almost 100 per cent and small farm production accounted for an increasingly large share of national maize production gains, even as white commercial farms responded to markets in vegetables and cut flowers. Beneath those impressive national numbers, however, lurked the statistical evidence that gains in national production had come from area expansion rather than increasing average yield.

By the late 1990 s and into the $2000-03$ period, average yields were declining substantially below the high water mark of 1.5 tons/ha average in the 1980s. Zimbabwe's food supply was in deficit by 2002 and inflationary prices meant that farmers were unable to purchase inputs and were forced to resort to recycling their old hybrid seed. In Malawi, where farmers had initially resisted adopting dent hybrid seed (preferring the flint 'maize of the ancestors'), their increasing use of hybrids had stalled as MH18, their successful semi-flint hybrid, proved susceptible to Gray Leaf Spot (GLS) disease.

In the meantime, Zimbabwean farmers, caught up in the hybrid revolution, had suffered a subtle and almost unnoticed loss of local knowledge of non-hybrid maize varieties. The homogenisation of maize types had resulted in an erosion of local knowledge about land race seed and a genuine loss of biodiversity of those types that had been dominant in Stage 1, especially flinty types. Farmers proved unable to sustain the high management requirements of the hybrids that needed fertiliser, annual seed purchases and input credits. The ideal field conditions needed by hybrids were only available to a few of those who needed to produce more as food or as a source of cash. Clearly, a transition in seed demand for Southern African maize farmers was underway.

\subsection{Stage 4: The search for yield stability, drought tolerance and resistance}

The 1990s were years of transition in the maize seed systems of Southern Africa. The modernist vision of uniformly expanding hybrid maize seed distribution seemingly continued apace but sources of instability began to appear. The first factor was the appearance throughout the century's final decade of general climate instability in Southern Africa, particularly in the agriculturally marginal areas where highyield/high-management hybrid varieties that assumed high management and ideal conditions were poorly adapted and had little stress tolerance. Farmers who might have wanted to opt out of annual hybrid seed purchase had few choices: they could recycle their own hybrid seed varieties at substantial loss of yield or buy the only commercially available OPV, Kalahari Early Pearl, an old dent that had poor disease resistance and poor yield. Its early maturity meant it might 'escape' drought but had little genuine stress resistance. High-management seed development had led farmers down what seemed to be a track to a dead end.

There were also the effects of the wider political ecology of seed within international trade and finance structures. Economic liberalisation and structural adjustment programmes in the early 1990s interrupted distribution of seed inputs. 
Zambia, for example, had underwritten its investments in marketing, maize seed research and fertiliser (and other input) costs by tapping booming world market prices for copper during the early 1970s, sustained in part by the Vietnam War and the Cold War. When copper prices crashed in the wake of the 1973 oil crisis and did not recover as some had predicted, Zambia's fertiliser subsidies that had so greatly benefited small-scale maize farmers had reached a whopping 17 per cent of the total national budget by 1988 . Urban maize price increases fostered urban unrest in 1986 and 1990 and President Kaunda's maize policy was a major campaign issue in the 1991 election that brought down his UNIP government. A sporadic liberalisation process followed, interrupted by the impact of regional drought. The contraction of credit and loss of price supports on more remote small-scale farms by the mid-1990s had reduced land planted to maize by more than 15 per cent and there was a relative decline in demand for improved F-1 seed, as many small farms reverted to older, less market-oriented grain crops like sorghum and millet, as well as to non-grains like groundnut, cassava and beans.

In Zimbabwe, the massive subsidies and credit schemes for black smallholder farms after independence in 1980 proved unsustainable. Political instability increased with the expiration of the Lancaster House agreement in 2000 and the invasion of commercial farms by war veterans and opportunists that has followed. Farm invasions, drought and rampant inflation disrupted flows of improved seed. The farm invasions also temporarily destabilised maize seed production that had been the hallmark of the hybrid period. Fertiliser use declined dramatically as a currency crisis disrupted input markets. These problems were particularly acute among the smallholders who, over the course of the 1990s, had become the mainstay of national maize production and seed purchases.

Zimbabwe's high-yield hybrid revolution has seemingly ground to a halt and maize began to appear in the urban black market at inflated prices. What has now emerged from the crisis of the early twenty-first century is a new economy of maize in Southern Africa. In the 2003 crop year, for example, 67 per cent of Zimbabwean maize farmers replanted hybrid seed - a sign of impending collapse of the hybrid revolution and a harbinger of the dawn of a new era.
There were, however, promising signs. Beginning in 1996, the Southern African Drought and Low Soil Fertility Project (SADLF) began to breed a new generation of seed types as a response to declining maize production in Southern Africa and the increasing role of smallholders. ${ }^{9}$ The new OPV seeds were fundamentally different in that they are synthetic (rather than composite) materials. Rather than being the result of recurrent selection of a single variety, the SADLF series were the progeny of 30-40 types of the CIMMYT tropical genetic pool, crossed and then selected from test plots deliberately stressed by low moisture and low fertility. That crossing and selection for stress tolerance highlighted the new seed types' 'flintiness' - a characteristic that signalled greater genetic diversity of the germplasm and brought qualitative changes in the maize reminiscent of flint maize varieties of the Southern African past. These qualities proved very attractive to farmers, including better storability, poundability, pleasing taste and a higher milling fraction (less wastage during de-hulling). ${ }^{10}$

From the beginning, the maize breeders in the SADLF project had in mind diversifying farmers' choices of seed type and recognising the complexity of their livelihoods by developing OPVs that they could replant from their own seed stocks (recycle). Moreover, they were breeding varieties that could thrive under conditions of low fertiliser use and either 'escape' drought or were tolerant to it. Instead of breeding new varieties under ideal conditions of moisture and fertility as had been the dominant paradigm, breeders in the SADLF project and national programmes began to subject their new seeds to stress and to cross more genetically diverse seed materials into the mix of new openpollinated varieties.

The strategy for developing a new generation of OPVs reflected a choice to ride a new wave in Southern African agriculture away from the intensive management of hybrid seeds that had been the leading edge of Southern Africa's successes of the last half of the twentieth century. In 1996/7, OPVs were planted on only about 7 per cent of the maize area in Southern Africa.

SADLF's specific strategy for this new approach to farmer seed selection was the 'Mother-Baby Trial' - a farmer participatory evaluation scheme 
that, since 1996, had tested farmer responses to new maize varieties in community and farmermanaged trials in ten countries of the region (Angola, Botswana, Lesotho, Malawi, Mozambique, South Africa, Swaziland, Tanzania, Zambia and Zimbabwe) (Snapp 2003). By 2004, there were 156 Mother-Baby Trial sites. At each site, the Mother Trial was a centrally located plot where a partner institution planted up to 16 varieties of hybrid and open-pollinated maize in demonstration plots for farmers to observe. Baby Trials brought four of those maize varieties selected by local farmers to each of eight farmers' own plots for their own management and observation. The structure of these two-tier Mother-Baby trials provided for farmer participation - women in particular - and solicited expressions of their preference of characteristics such as flour texture, poundability, hand de-hulling, ear size, disease resistance and, above all, storability. The Mother-Baby concept has decentralised a farmlevel discussion about maize seeds and has encouraged a focused farmer-led demand for particular seed at particular agro-environmental niches. The SADLF project envisioned farmer engagement with decentralised seed distribution - a demand-driven seed system that will foster institutional change as private seed companies, local NGOs, international donors and government agencies respond to the needs of the small farms that have become Africa's primary maize producers. The plan also anticipated that farmers would gain solid experience-based knowledge for seeking out favourite seed varieties in local shops or to initiate communitybased seed production of open-pollinated varieties. Selection by farmers from trial plots (Mother-Baby) has now reappeared under new names in Stage Five (see below).

\subsection{Stage 5: New acronyms and new seed in the twenty-first century}

The most recent intervention in African seed has moved from international agricultural research institutes (such as CIMMYT) and national programmes to large-scale donors working in public-private cooperation that intertwine global seed companies with international foundations. The scale of these efforts is massive, emphasising regional programmes, biosafety treaties and high technology in seed research and production. These efforts place seed development in the hands of technicians that intend to employ conventional breeding, markerassisted breeding and biotechnology (i.e. genetic engineering) in establishing a new menu of seeds from which African governments, private merchants and commercial farmers can choose. These groups' public statements argue that seed improvement will benefit all farmers, including Africa's smallholders.

The new array of participating groups comprises a bewildering mix of acronyms that mark new actors and combinations of players in Africa's seed bazaar. These groups include the FARA (Forum for Agricultural Research in Africa); AGRA (Alliance for a Green Revolution in Africa); ABSN (the African Biosafety Network) and the African Agricultural Technology Foundation (AATF), among others. The list of private corporate participants is also notable, and includes BASF, Bayer CropScience, Dow AgroSciences, Dupont, Monsanto and Syngenta - multinational corporations that reflect the direct interests of the chemical/pharmaceutical/seed conglomerates from Europe, the USA and East Asia.

The most visible of these may well be the Water Efficient Maize for Africa (WEMA) partnership announced in March 2008 by Monsanto, AATF, CIMMYT, the Bill and Melinda Gates

Foundation, the Rockefeller Foundation and the Warren G. Buffet Foundation. This consortium is working directly with the national seed research systems in Kenya, Mozambique, South Africa, Tanzania and Uganda. The WEMA effort is currently in its research and development stage, but has already worked in cooperation with the COMESA (Common Market for Eastern and Southern Africa) to develop a regional treaty on biosafety that, in effect, clears the way for access for new drought-resistant seed varieties that will eventually include genetically modified varieties developed by the international seed companies. In the first year of the project, Monsanto alone assigned 13 scientists based in South Africa and Kenya to work full-time on the project. In the next phase of the project, the group foresees setting up farm-level seed trials akin to the Mother-Baby system used by the SADLF project of CIMMYT a decade earlier. ${ }^{1}$

This new stage of international cooperation may well represent a sea change in the genetic makeup of African cereal seeds. Smallholder farmers in Africa will be consumers of seed as a finished 
industrial product, not selectors of phenotypic traits they favour locally. African farmers will plant crops with traits isolated directly via DNA extractions in corporate genetic labs located in Iowa, Switzerland, Germany or South Africa rather than by breeders or farmers working in African fields. This high-tech seed production is unlikely to take place on or near smallholder farms. Moreover, the new system will seek to wrap African farmers in networks of finance, markets and technology transfer that are regional and global and assume the permeability of national borders and ecologies.

\section{Notes}

1 This analysis, of course, assigns the North African littoral to the Mediterranean ecological zone rather than to tropical and sub-tropical Africa.

2 The most thorough survey of crops drawn from travel accounts is by Donald Crummey (1983).

3 Methods for collecting production data have changed over time. Figures from the 1960s are the 'best estimates' of local and foreign experts, while data from the years 1974-9 were based on small-scale surveys. Since 1979, the sample size has been doubled and these data are therefore probably the most accurate. Thus, while absolute figures may be problematic, trends would appear to be accurately indicated. For more, see Watt (1988).

4 Regions in Italian East Africa were based roughly on the principle of consolidating precolonial provinces. The figures here are relative since Italian colonial authorities in 1938 reported rounding of the statistics (Cierri and Bortolozzi 1939).

5 Cross-breeding later changed Hickory King to a more productive 10 - and 12-row variety. Joseph Burtt-Davy (1914: 286-9) reports that Hickory King arrived on the high veld from Natal before 1898, but offers no specific date.

6 In genetics, heterosis is the tendency of a crossbred organism to have qualities superior to those of either parent. In plant breeding, it aims to breed seeds for increased vigour or general health, resistance to disease and other
Seeds have long been commodities in developed world agriculture. In the immediate future, African farmers will receive their seeds from a global political structure that anticipates, perhaps wishfully, economic and political stability. Those expectations of development specialists failed at the end of the twentieth century. Will seed selection by African farmers in the twenty-first century take place in an ideal free market of infinite choice or in real-world conditions fraught with uncertainty of supply, climate fluctuations and unintended consequences within complex local ecologies?

superior qualities that are often manifested in hybrid organisms.

7 Heterosis is used to increase yields, uniformity and vigour. Hybrid breeding methods are used to produce new varieties of key cereal crops, such as maize, sorghum and rice, as well as various vegetable and oil seed crops (e.g. broccoli, sugar beet, onion, spinach and sunflowers).

8 In the early twenty-first century, virtually all commercial seed comes from single-cross breeding techniques.

9 The Southern African Drought and Low Soil Fertility Project (SADLF) was a collaborative effort between the International Maize and Wheat Improvement Center (CIMMYT) and national agricultural research programmes of the Southern Africa Development Community (SADC) region. Begun in 1996, SADLF was funded by the Swiss Agency for Development and Cooperation (SDC) and the Rockefeller Foundation at approximately US $\$ 500,000$ per year.

10 According to SeedCo maize breeder, Mike Caulfield (pers. comm. 2010), flintiness has become more common in North American maize breeding as well, perhaps because of its increased milling fraction.

11 References to this new phase of seed development and biosafety are widely available on the internet. For an example, see Johnson (2009). 


\section{References}

Beinart, W. and Coates, P. (1995) Environmental History: The Taming of Nature in the USA and South Africa, London: Routledge

Burtt-Davy, J. (1914) Maize: Its History, Cultivation, Handling, and Uses. With Special Reference to South Africa, London: Longmans, Green and Co

Byerlee, D. and Eicher, C.K. (eds) (1997) Africa's Emerging Maize Revolution, Boulder CO: Lynne Rienner Publishers

Cierri, R. and Bortolozzi, E. (1939) La Produzione Cerealicola dell'Africa Orientale Italiana nel 1938, Florence: Istituto Agricole Coloniale

Crummey, D. (1983) 'Ethiopian Plow Agriculture in the Nineteenth Century', Journal of Ethiopian Studies 16: 1-24

Diamond, J. (1997) Guns, Germs, and Steel: The Fates of Human Societies, New York: Norton

Governo Generale dell'Africa Orientale Italiana, Direzione Superiore degli Affari dell Colonizzasione e Lavoro (1940) Fascicolo 1925, Florence: Istituto Agronomico delle Colonia

Istituto Agricolo Coloniale (1946) Main Features of Italy's Actions in Ethiopia 1936-1941, Florence: Istituto Agricolo Coloniale

Johnson, R. (2009) 'Flashback: Revisiting WEMA - One Year Later', Monsanto Today, 11 May,
www.monsanto.com/newsviews/Pages/WEMAOne-Year-Later.aspx (accessed 6 April 2011)

Larebo, H.M. (1994) The Building of an Empire: Italian Land Policy and Practice in Ethiopia 1935-1941, Oxford: Clarendon Press

McCann,J.C. (2005) Maize and Grace: Africa's Encounter with a New World Crop 1500-2000, Cambridge MA: Harvard University Press McCann, J.C. (1995) People of the Plow: An Agricultural History of Ethiopia, Madison WI: University of Wisconsin Press

Snapp, S. (2003) 'Quantifying Farmer Evaluation of Technologies: The Mother and Baby Trial Design', in M.R. Bellon and J. Reeves (eds), Quantitative Analysis of Data from Participatory Methods in Plant Breeding, Mexico DF: CIMMYT

Ufficio Agrario della Colonia Eritrea (1940) 'Le Culture Cerealocole, Leguminose ed Oliefere nelle Territorio di Macalle', Eritrea Fascicolo 650, typescript

Watt, Ian (1988) 'Regional Patterns of Cereal Production and Consumption', in Z.A. Zein and H. Kloos (eds), The Ecology of Health and Disease in Ethiopia, Addis Ababa: Ministry of Health 